\title{
An Approach to the Historical Novel
}

WHAT IS THE HISTORICAL NOVEL?

When critics discuss literary groups and genres, they are usually doing more than indulging in the pleasures of the taxonomical imagination. Genres help us sense the lay of the literary land. They imply questions and sometimes answers: we see a forest, or at least clumps of trees, instead of trees. In other parts of life, we constantly make distinctions that are like generic distinctions in literary studies, and they matter. As we know, an attempt to correct social injustice may dictate very different actions depending on the groups it singles out for attention. Debates between microhistorians and macrohistorians hinge on the same problem; they also remind us that the time span we choose to think about has a significant impact on the conclusions we draw about a given topic. It may be true that in the long run, we are all dead, but such a perspective is more useful to a mystic than to a mercenary. When we experience a work of literature, we employ in a refined and complex way our general ability to see the world in terms of significant groups and patterns. Making sense of a work rests upon knowing what to expect from it, understanding how to take it in. This in turn implies that we have a sense of what sort of thing it is, how it works, what its rules are. Beyond that, generic assumptions allow us-indeed, force us-to focus on some things at the expense of others; they can make certain aspects of a text disappear or seem trivial. If I begin this book about Scott and form in the historical novel by asking about the generic status of historical fiction, then, my purpose 
is not merely to devise a set of labels. Questions of genre are questions of meaning and literary effect. ${ }^{1}$

What is the historical novel? In attempting to answer this question, it would seem advisable, before plunging into speculations about historiography and the nature of a truly historical outlook, to ask what sort of term "the historical novel" is in the first place. How does it differ from other groups of novels-the picaresque novel, the industrial novel, the sentimental novel, the eighteenth-century novel? Which is it most like? A simple but accurate answer is that the term historical novel denotes a kind of novel which can be differentiated from other groups of novels not in terms of a defining compositional technique (the picaresque novel), nor through its power to evoke a set of emotions (the gothic or sentimental novel), and certainly not in terms of the period in which it was written (the eighteenth-century novel). Instead, the principle of differentiation involves the milieu represented, which makes the closest parallel in our list the industrial novel. Though it seems fair to say that the industrial novel is a narrower category, it is the same sort of category as the historical novel.

A convenient way of extending this simple, intuitive notion that historical novels are works that in some way represent historical milieux is to speak in terms of fictional probability. A character or incident in a novel can be probable in either or both of two ways. We usually think of probability as involving fidelity to the external world that a work represents. Some eighteenth-century readers of Clarissa found Mrs. Sinclair's house in London improbable because they could not believe that such carefully contrived dens of iniquity actually existed. One might complain that Clarissa herself violates probability in this sense because she is too good to be true-we have never met anyone like her in the world in which we live. In the historical novel, anachronisms and mistakes of historical fact are responsible for breaches of

I. My discussion employs the notion of genre in a more extended way than its common use to identify certain large classes of works, such as epic, tragedy, or novel. I believe, drawing upon the work of Ralph W. Rader, that we make sense of works by intuitively classing them according to a whole range of increasingly specific distinctions, from the most general (literature as opposed to nonliterature) to the most specific (one work as opposed to another by a given author). For Rader's views on genre, see "The Concept of Genre and Eighteenth-Century Studies," in New Approaches to Eighteenth-Century Literature, ed. Phillip Harth (New York: Columbia University Press, 1974), pp. 79-I I 5. 
probability in this sense. But probability can also depend upon how consistently a work follows its own internal rules and patterns. Soliloquies in drama are probable in this second sense, but not in the sense of being faithful reproductions of the behavior we expect from our fellows in their everyday affairs. In general, the more stylized a work becomes, the more these two kinds of probability diverge; the more directly mimetic it is, the more they coalesce. Probability involves our sense of a novel's "fit," both the way it fits the world it imitates and the way its parts fit together to produce a unified whole. A novel's power to illuminate life and its intrinsic beauty as a formed work of art depend in large measure on its probability in both senses. ${ }^{2}$

The concept of fictional probability implies a way of defining historical fiction. We can say that while in most novels probability stems from our general ideas about life and society, in historical novels the major source of probability is specifically historical. Though many kinds of novels may incorporate a sense of history, in historical novels history is, as the Russian Formalists would put it, "foregrounded." When we read historical novels, we take their events, characters, settings, and language to be historical in one or both of two ways. They may represent societies, modes of speech, or events that in very fact existed in the past, in which case their probability points outward from the work to the world it represents; or they may promote some sort of historical effect within the work, such as providing an entry for the reader into the past, in which case the probability points inward, to the design of the work itself. In Waverley, Fergus MacIvor has both internal and external probability, while Edward Waverley's probability rests primarily on the way in which he furthers the novel's historical design. Fergus is a faithful composite picture of the Highland Jacobite nobility, providing a good external portrait of them and also representing the historical weaknesses that in Scott's opinion doomed their movement. Waverley, on the other hand, is the reader's entry into the novel. He functions primarily as a fictional device, allowing the historical import of the novel to be felt with maximum force. The idea of internal probability allows us to see why a work

2. W. J. Harvey, Character and the Novel (London and Ithaca, I965; rpt. Ithaca: Cornell University Press, I968), pp. II-I3, discusses these two kinds of fictional probability, which answer roughly to the New Critical terms "coherence" and "correspondence"; subsequent references to Harvey appear in my text. 
can become more historical, not less historical, if it rearranges individual aspects of the historical record for the sake of demonstrating a larger pattern. ${ }^{3}$

Historical novels, then, are works in which historical probability reaches a certain level of structural prominence. This may seem an impotent and lame conclusion, objectionable on several counts. It is negative and minimal. It is vague in terms of what counts as historical. It creates distinctions of degree, not kind; and in particular, it does not indicate the kind of prominence history must have in the structure of a truly historical novel. In fact, these qualities are virtues. Because the definition is vague in terms of what counts as historical, it leaves open the possibility that history may mean different things in different works. The definition works in terms of differences of degree, not kind, but it should: the modern historical novel arose as part of the rise of historicism, which made a sense of history part of the cultural mainstream and hence available to novels in general, not simply to historical novels. But the definition's greatest strength is that it does not specify what role history must play in a novel's structure if we are to consider that novel a work of historical fiction. One of my main contentions is that we cannot make sense of historical fiction unless we recognize that history plays a number of distinctly different roles in historical novels. My second and third chapters will explore the three main functions history performs in the classical historical novel, and it will be necessary to create a further set of distinctions when we discuss Scott's works. A negative, minimal definition of historical fiction leaves the way clear for these necessary distinctions. ${ }^{4}$

3. The reader will notice in my account even a novel's internal probability ultimately serves referential, not self-referential ends: this might be a liability in dealing with some kinds of fiction but seems an asset in dealing with historical fiction.

4. Roland Barthes, "Historical Discourse," in Introduction to Structuralism, ed. Michael Lane (New York: Basic Books, I970), pp. I 45-55, defines a distinctive kind of historical discourse characterized by its production of a historical "reality effect." Whatever its other merits, such an approach cannot be used to solve the problem of defining historical fiction by discovering its basic representational means. As we shall see in Chapter 2, the structures that embody historical probability in historical fiction exist at all levels of generality, often at a level of allegorical abstraction very far removed from the concreteness or pseudo-concreteness of "historical discourse." Wolfgang Iser, The Implied Reader: Patterns of Communication from Bunyan to Beckett (Baltimore: Johns Hopkins University Press, I974), pp. 8I-I00, discovers in Waverley a variety of historical discourse, with instructive results. Though he does de- 
In most respects, historical fiction depends upon the formal techniques and cultural assumptions of the main traditions of the novel. Because of this dependence, it does not have a significant history apart from the history of the novel as a whole. What is often called the classical historical novel begins with Scott; but the important line of fictional development runs not from Scott to the historical novelists who followed him, but instead from Scott to such masters of European fiction as Balzac, Dickens, and even (so argues Louis Maigron) Flaubert. ${ }^{5}$ The authors who produce the best historical novels after Scott tend, with the exception of Cooper and Tolstoy, to be masters of other kinds of writing, who enter the field with one or two attempts, as Dickens, Thackeray, and Hugo do. Georg Lukács is in my opinion essentially accurate in describing the history of the novel as a great stream from which tributaries branch off, only to rejoin and further enrich it in due course. Scott's works form such a tributary: he branches off from the eighteenth-century novel, discovers in artistic terms the rich significance of history, and then reunites with the mainstream of nineteenth-century fiction through his influence on Balzac, enriching it with new materials, insights, and techniques. ${ }^{6}$

Since they lack a history of their own, the most useful way to group historical novels historically is in terms of coherent movements of the novel as a whole, and of the esthetic and cultural presuppositions that underlie them. The realist novel, which begins with Richardson and finds its greatest achievement in the works of Eliot and Balzac and

fine one aspect of the immediate texture of Scott's writing, he neglects the larger structures that create a novel's meaning and effect, and he ignores the self-consciousness with which Scott employs, and we accept, various fictional conventions. For a critique of Iser on Scott, see Richard L. Stein, "Historical Fiction and the Implied Reader: Scott and Iser," Novel, I 4 (I98I), 21 3-3I.

5. Louis Maigron, Le roman historique à l'époque romantique: Essai sur l'influence de Walter Scott (1898; new ed. Paris: Champion, I 912). An important recent attempt to reinstate Scott as a source of the realist novel is George Levine, The Realistic Imagination: English Fiction from Frankenstein to Lady Chatterley (Chicago: University of Chicago Press, I $98 \mathrm{I})$.

6. The Historical Novel (1937), trans. Hannah and Stanley Mitchell (London: Merlin, I 962). One general property of literature set in the past is that it can provide a privileged area for formal and thematic innovation. In his historical dramas, John Banks made the transition from Restoration tragedy to the sentimental drama of the eighteenth century: see Laura Brown, English Dramatic Form, 1660-1760: An Essay in Generic History (New Haven: Yale University Press, I98I), pp. 95-97. Shakespeare's history plays may well have served a similar function in his career. 
Tolstoy, is such a movement. I shall call such works "standard" novels; the group of historical novels which derives its unity from its relationship with standard fiction then becomes "standard historical novels." These works form the subject of this book. They all employ the formal techniques of standard fiction, and in particular, they use the plotted action, which creates in the reader a pattern of hopes and fears for one or more protagonists, as their formal basis.' They also share with the standard novel a set of broad cultural assumptions that provide the grounds for their intelligibility and are the ultimate source of their "realism." The situation of historical fiction in our own century becomes more complex. As the novel in general changes, new forms of historical fiction emerge. But strong continuities with nineteenth-century forms also persist in such distinguished historical novelists as Marguerite Yourcenar or H. F. M. Prescott. ${ }^{8}$

I have suggested that no single quality of historical insight defines historical fiction. But since we have narrowed our sights to the standard historical novel, can't we say something more specific about the kind or kinds of historical vision they embody? We can indeed, but

7. The concept of the "plotted action," which I employ throughout, derives from Ralph W. Rader's extension and revision of R. S. Crane's "form of the plot," which Crane develops in "The Concept of Plot and the Plot of Tom Jones," in Critics and Criticism: Ancient and Modern, ed. R. S. Crane (Chicago: University of Chicago Press, I952), pp. 616-23. According to Rader, the plotted action gives form to a novel by creating in the reader a dynamic pattern of hopes and fears about the fate of the protagonist: "the author pits our induced sense of what will happen to a character against our induced sense of what we want to happen to him, our hopes against our fears, in order to give the greatest pleasure appropriate to their resolution." For a fuller and more technical definition, see Rader, "Defoe, Richardson, Joyce, and the Concept of Form in the Novel," in Autobiography, Biography, and the Novel, by William Matthews and Ralph W. Rader (Los Angeles: William Andrews Clark Memorial Library, I 973), pp. 33-34.

8. Joseph W. Turner, "The Kinds of Historical Fiction," Genre, I 2 (I979), pp. $333-55$, produces an interesting typology of kinds of historical fiction in the twentieth century. He also briefly points out some of the problems inherent in the attempt to define historical fiction by differentiating it from historiography, noting that this procedure tends to reduce historiography to one single thing, and fiction to another single thing. In my view, a valid differentiation between historiography and historical fiction would require an exhaustive typology of subclasses of the two kinds of works. Even then, the complex set of resulting distinctions would almost certainly have to exist at a high level of generality, involving such matters as the cognitive claims of art and the truth values of statements in different kinds of discourse. Such speculations might have considerable general interest but would probably have little heuristic value for understanding individual works. 
only within limits. The historian Herbert Butterfield and the literary critic Avrom Fleishman have both tried in different ways to define the quality historical novels share, and their discussions are useful here. Both define historical fiction by differentiating it from historiography. For Butterfield, historiography attempts to "make a generalisation, to find a formula," because it views history as "the whole process of development that leads up to the present." The historical novel, by contrast, attempts to "reconstruct a world, to particularise, to catch a glimpse of human nature." The task of the historical novelist is to render the unique "atmosphere" of an age in the past, to "recapture the fleeting moment." For Fleishman, by contrast, the historical novelist accomplishes something more like the task Butterfield sets the historian: "What makes a historical novel historical is the active presence of a concept of history as a shaping force." Both critics are clearly drawing on the achievements of historicism for their definitions, a procedure that seems entirely in order since the rise of the historical novel is bound up with the rise of historicism in general. But Butterfield invokes what we might call a minimal historicist vision; Fleishman, historicism at its most powerful and dignified.'

Identifying the historicity of historical novels with "the active presence of a concept of history as a shaping force" seems to have much to recommend it. Probably the most important aspect of the historicist view of the past is its recognition that history shapes human beings through specific and unique social mediations. This need not imply the view often attributed to Hegel-the idea that history is a vast teleological progression leading relentlessly toward one divine event - though such a belief is one of its extreme potentialities. It does involve a sociological sense of both past and present, a recognition that societies are interrelated systems which change through time and that individuals are profoundly affected by their places within those systems. The greatest modern critics of nineteenth-century fiction from a historical point of view, whatever their other differences, agree that the creation of this grasp of social-historical milieux is its principal achievement. For Erich Auerbach, it is the prerequisite for a fully serious treatment of everyday life; for Lukács, it involves a fundamen-

9. Herbert Butterfield, The Historical Novel (Cambridge: Cambridge University Press, 1924), p. I I 3; Avrom Fleishman, The English Historical Novel: Walter Scott to Virginia Woolf (Baltimore: Johns Hopkins University Press, 1971), p. I 5. 
tal discovery concerning the meaning of historical process itself. Both critics describe this development as the discovery of "the present as history," a phrase which derives ultimately from Hegel. In asserting that historical novels are defined by their sense of "history as a shaping force," Fleishman would thus appear to have rendered them an important service: he has acquitted them of the charge of portraying mere local color, finding in them instead the historical insights we associate with historicism at its most developed. ${ }^{10}$

But Butterfield, writing at a time when valuing historical particularity caused critics less embarrassment than it does now, is closer to the truth about the historical probability that serves as a basis for the standard historical novel. The problem with Fleishman's mode of definition is that it saves too much too quickly, giving historical fiction a cognitive dignity that is unearned. The works of Harrison Ainsworth betray no insight whatever into "history as a shaping force," but we unhesitatingly call them historical novels. Fleishman's discussion quickly slides from defining historical fiction to finding a criterion for "authentic" historical fiction, a separate issue for which his maximal kind of definition is entirely appropriate.

The recognition that human beings are part of a larger historical process is not the source of the distinctively historical probability that distinguishes standard historical fiction, though the best historical novels certainly convey it. The probability that distinguishes standard historical novels rests on a simpler notion-the realization that history is comprised of ages and societies that are significantly different from our own. We can call this idea the recognition of "the past as past"11 (Ainsworth's fiction doesn't really measure up to this crite-

I0. Since "historicism" has been given a pejorative meaning by certain writers (especially Karl Popper), let me make clear that I use the word to refer to the enriched sense human beings gained of history about the time of the French Revolution, involving a new awareness of the systematic otherness of societies in the past, and a new interest in the process by which the past becomes the present. Useful introductions to historicism include Isaiah Berlin, Vico and Herder: Two Studies in the History of Ideas (London: Hogarth, 1976), and Friedrich Meinecke, Historism: The Rise of a New Historical Outlook (1936), trans. J. E. Anderson (London: Routledge and Kegan Paul, I 972). For a useful discussion of the definition of historicism, see Maurice Mandelbaum, History, Man, and Reason: A Study in Nineteenth-Century Thought (Baltimore: Johns Hopkins University Press, I97I).

I I. In my discussion, I am assuming that historical novels depict societies that are in fact different from our own. Now it is possible to write a historical novel that at- 
rion either, but it is at least possible to recognize in his sensationalistic use of historical atmosphere a debased version of it, whereas any connection whatever with a notion of historical process or the present as history is in his case unimaginable.) The recognition of the past as past can lead to a sense of history as a process, and perhaps it ought to, but in fact it has not always done so in historical fiction.

By arguing that historical fiction need not view history as a process, I am parting company not only with Fleishman but with Lukács as well, though in a different way. For Lukács, the historical novel arises in the works of Scott when Scott discovers on an esthetic level that history is a process in which the past acts as the necessary precondition for the present. Unlike Butterfield or Fleishman, however, Lukács simply isn't interested in the problem of defining historical fiction, and given his distrust of "mere formalism," it is hard to see how he could be. He pursues instead the question of how the historical spirit comes to consciousness in literature. With more consistency than other writers who hold similar views concerning what is truly historical about historical novels, Lukács believes that historical fiction does not constitute a genre separate from the European realist novel as a whole. In his version of Marxist esthetics, a truly separate genre can arise only from a new vision of reality, and the truly historical novel shares (and in fact helped to create) the vision of reality we find in genuinely realistic novels. Historical fiction is thus part of a larger fictional genre, realist fiction, which is characterized by the mode of knowledge it embodies. This mode of knowledge provides, in the process he calls "preparatory esthetic processing," a necessary but not sufficient condition for the creation of realist fiction. ${ }^{12}$

My discussions of Lukács, Butterfield, and Fleishman have revealed

tempts to show just the opposite-that life is essentially the same in all ages. Anatole France's Les dieux ont soif is written from such a perspective. But even this sort of novel must at least show that life seems to be different, if only to refute that claim. The very notion of history implies change over time: the question that Les dieux raises is how important the areas are in which change occurs. For most historical novels, their importance is considerable.

I 2. Béla Királyfalvi, The Aesthetics of György Lukács (Princeton: Princeton University Press, 1975), pp. I04-5. Királyfalvi is a useful guide to Lukács's later works, but he generally gives references only to the Hungarian translations of Lukács. The passage here will be found in the original in Lukács, Probleme der Ästhetik (Berlin: Luchterhand, 1969), p. 765. 
a number of fundamental differences among them, but they are united in believing historical fiction to be fundamentally a mode of knowledge. Such a view has its attractions. Who would want to deny that the best historical fiction can add to the richness of our sense of history, or that the structuring of history in great historical fiction may have cognitive value? Narrativist philosophers of history have recently argued with some persuasiveness that historical understanding itself may proceed according to the logic of narrative discourse, not of science. ${ }^{13}$ But it seems important for a number of reasons to oppose the idea that historical novels, or even standard historical novels, embody a defining vision of history in more than a minimal way.

Such an idea can become quickly and narrowly prescriptive in practice, blinding us to the workings of novels that embody a vision of history we do not respect. It is tempting to say that works which embody a historical vision we find uninteresting or unacceptable, or that seem to have no historical vision at all, are not "really" historical novels. But it is more useful to discriminate between great and mediocre historical novels than to exclude imperfect works from the group-a procedure that logically tends to produce a group containing one and only one true member. A different consequence appears in Fleishman's criticism. As we have seen, he believes that historical novels are characterized by "the active presence of a concept of history as a shaping force." He is also interested in tracing the history of historical fiction in England, which of course implies that there is a significant history to trace. Each of these premises raises problems. Combined, they cause him to exaggerate and homogenize the level of historical consciousness in the works he considers. Only by doing so can he produce a developing tradition of English historical fiction.

The search for a specific way of perceiving history which defines historical fiction is in my view a local manifestation of the understandable but unacceptable desire to separate literary discourse from "scientific discourse" and thus to save for literature its own distinct significance. This view, which places great stress on differentiating be-

13. W. B. Gallie, Philosophy and the Historical Understanding (London: Chatto \& Windus, 1964). For a discussion of the narrativist historians and their rivals, see Cushing Strout, The Veracious Imagination: Essays in American History, Literature, and Biography (Middletown: Wesleyan University Press, 198I), pp. 3-28. 
tween true and false poetic modes, is most familiar as one of the cornerstones of the New Criticism as practiced by Cleanth Brooks and others. Lukács from his Marxist point of view has come up with a similar if somewhat more elegant procedure involving three levels of discourse-everyday speech, scientific discourse, and (mediating between the two on a whole series of intermediate levels) the language of literature. This is not the place to weigh the merits of such views extensively. I shall merely say that in my view "scientific discourse" in the sense required by Brooks and the others has been shown not to exist; their argument is based upon a false dichotomy. Literary works in general do not embody a distinct mode of knowledge, though they certainly can impart knowledge. Though literary works can have cognitive claims, they are in the first instance verbal constructions designed to create certain effects through the disposition of their parts. ${ }^{14}$

For our present purposes, the idea that historical fiction is a mode of telling the truth about history is objectionable chiefly because it does not account for the very different formal status that visions of history have in fact assumed in historical fiction. Such a definition excludes works we all call historical novels. Furthermore, if we adopt such a definition, we must conclude that most great nineteenth-century novels are historical novels, which renders the concept "historical novel" useless as a conceptual aid and falsifies the strong intuitive impression that leads readers to give the group a name in the first place. ${ }^{15}$ In practice, such an emphasis also tends to exclude or preclude problems of artistic form and effect, operating as if historical novels conveyed unmediated historical doctrine. Finally, the idea that historical fiction is a mode of historical knowledge leaves as a com-

I4. For Lukács's three levels of discourse, see Die Eigenart des Ästhetischen, 2 vols. (Berlin: Luchterhand, I963), II, I I-I92; and Királyfalvi, pp. 88-IO2. For an incisive critique of the New Critical distinction between poetic and scientific discourse, see R. S. Crane, The Languages of Criticism and the Structure of Poetry (Toronto: University of Toronto Press, I953).

I 5. Fleishman, p. I 5 , notes and is properly suspicious of John Lukacs's assertion that "In the broad sense every novel is a historical novel," in Historical Consciousness, or The Remembered Past (New York: Harper, I968), p. I I8. In a certain sense, Emma and Old Mortality, which were both published in 18 I6, are also both "historical" for readers today, because they are implicated in the history of their own times. But an important difference remains between the degree to which a desire to depict history dominates their structures. 
plete mystery what is surely the most striking fact about these works. Why do the finest historical novels, with the single exception of War and Peace, seem flawed when compared with the best standard fiction? The lack of a great tradition of historical fiction is remarkable. From a point of view that sees history as one kind, and potentially an intractable kind, of material to receive esthetic shaping, it may perhaps be explained.

\section{THE PROBLEM WITH HISTORICAL NOVELS}

My definition of historical fiction has been primarily negative. I have tried to show that historical novels do not constitute a strongly unified, independent genre. The most we can say is that there are groups of historical novels, united by their dependence on broader fictional traditions, which constitute significant objects of critical attention. The group with which I am concerned, standard historical novels, shares the conventions of the realist novel; they are also united, in a minimal way, by incorporating within their systems of fictional probability a sense of the past as past. But as a result of these unifying factors, historical novels have in common a third characteristic-a shared problematic, which (as my next chapter will show) assumes different degrees of prominence in different works, depending primarily on the end to which they employ history.

The historical novel raises in an acute form a question common to all mimetic works of art-the relationship of the individual to the general, of particulars to universals. Such problems tend to remain submerged in most literary works. Several things bring them to the surface in the historical novel. Because historical novelists depict ages significantly different from their own and may aspire to represent the workings of historical process itself, they are faced with the task of creating characters who represent social groups and historical trends. But creating such characters involves certain inherent difficulties. This is a major reason for the problem with historical novels.

Human beings live at a number of different levels of generality. They are individuals, with unique thoughts, feelings, and ideas; they are members of small social groups such as families; they are also members of larger groups, of cities, regions, nations, races; finally, they are human beings in the widest and most general sense, as op- 
posed to the rest of nature. As we move up the scale from particularity to generality, we become interested in different characteristics of the same individuals. The higher we go, the more we focus on the general and representative at the expense of the specific and idiosyncratic. The question that faces mimetic works in general and historical novels in a particularly acute form is how much of the scale a literary work can represent. If such literary forms as the standard novel have evolved in such a way that they deal most successfully with one segment of the spectrum, while historical novels by their very nature must treat a broader or different segment, we might expect standard historical fiction to have had only partial esthetic success.

The problem I have raised was very much a part of the intellectual milieu from which the historical novel arose. At about the time when Scott was inventing the historical novel in its modern form, Hegel was at work on history in a different way. One way of approaching Hegel's philosophy of history is to see it as an attempt to solve just this problem, for the dialectic is a device that bridges the gap between particulars and universals. Whatever we think of Hegel's system as a solution, we can understand why the problem of the relationship between particulars and universals interested him. The discovery that past ages are crucially different from the present and from each other challenges radically the belief that any assumptions about human beings are universally valid. It is only natural that philosophers should attempt to solve this problem. Hegel, it is worth adding, believed that Scott's historical fiction provides no solution at all: it was for him all particularity, presenting merely a "detailed portraiture incorporating all the minutiae of the age, in which the deeds and fortunes of a single individual constitute the work's sole futile interest and wholly particular matters are all put forward as equally important." 16 Even Homer nods.

The issue at hand involves some of our most basic, irreducible, and unprovable beliefs about human existence. Questions about mimesis in art are ultimately questions about what we think is centrally im-

I6. G. W. F. Hegel, Lectures on the Philosophy of World History, Introduction: Reason in History, trans. H. B. Nisbet (Cambridge: Cambridge University Press, I 975), p. I9. Hegel's attempt to create a system that sees history as universal but at the same time as utterly concrete and particular is stressed throughout George Dennis O'Brien's helpful Hegel on Reason and History (Chicago: University of Chicago Press, 1975). 
portant about human beings. In the following pages, I intend to describe the ideological underpinnings of a variety of beliefs about mimesis in novels, and to indicate the reason for the choice I make among them. I hope that the position I take will recommend itself by its usefulness for understanding the workings of historical fiction. From what I have already said, it will be apparent that I have little of interest to offer those who believe that novels do not mirror external reality in any important sense.

I am familiar with two main views concerning the mimetic scope of prose fiction, and I want to describe their implications rather fully. The view that in my opinion characterizes most English-speaking criticism in this century locates the mimetic power of the novel at both ends of the human spectrum simultaneously. ${ }^{17}$ It holds that good novels attempt to depict individual human beings in their mental complexity and spiritual depth; to the extent to which these novels succeed in doing so, they touch upon the most lasting, universal aspects of humanity in general. The intermediate levels involving society, nation, and history are either irrelevant or valuable only insofar as they reveal the universal through the individual. For convenience and despite the gracelessness of the term, we may call this an "individualist" view of the novel. This view often (though not necessarily) leads to a devaluation of interest in plot, that element of the novel which shows a character interacting with a larger social framework. Patterns of words and images instead become the central expressive techniques of the novel. When this tendency is carried far enough to imply an attack not merely on plot but on character, we begin to leave the realm of a mimetic conception of the novel altogether, and the possibility of representing society, much less history, as more than aspects of an individual vision diminishes to nothing. ${ }^{18}$

In sharp contrast to the individualist view of the novel is the idea that novels can represent the entire spectrum of human existence. This belief rests upon the assumption that there is a seamless connec-

17. Lionel Trilling would seem at least a partial exception to this trend, but the strenuousness of his effort to argue for the importance of "manners" in the novel itself testifies to the strength of the "individualist" view he is trying to broaden. He stresses the importance of historical difference in his last published fragment, "Why We Read Jane Austen," TLS, 5 March I976, p. 25 I, col. 2.

18. Harvey, pp. I $91-217$, provides a useful discussion of "The Retreat from Character" and "The Attack on Character" in modern criticism of the novel. 
tion between all levels of human existence. If any one level is presented clearly enough, it implies all the others. This is the view of Lukács. We can adapt his own terminology to call such a view "typicalist." For Lukács, great literature contains "typical" characters who concentrate within themselves all levels of human existence. If he is right about the novelist's ability to create typicality in literature, there should be no inherent formal problem in creating great historical fiction.

It is important to examine the ideas that underlie these two positions, and particularly what they presuppose about the meaning, or lack of meaning, of history. We may begin with a viewpoint that Aldous Huxley expresses succinctly and as a foregone conclusion in his essay on Piranesi:

Any given work of art may be represented as the diagonal in a parallelogram of forces-a parallelogram of which the base is the prevailing tradition and the socially important events of the time, and in which the upright is the artist's temperament and his private life. In some works the base is longer than the upright; in others the upright is longer than the base.

Piranesi's Prisons are creations of the second kind. In them the personal, private and therefore universal and everlasting upright is notably longer than the merely historical and therefore transient and local base. ... His concern is with states of the soul-states that are largely independent of external circumstances, states that recur whenever $\mathrm{Na}$ ture, at her everlasting game of chance, combines the hereditary factors of physique and temperament in certain patterns. ${ }^{19}$

Here we have most of the characteristics of the point of view I have called "individualist." There is the assumption that socially significant events and private life are sharply distinct, that the soul is "largely independent of external circumstances." Accompanying this belief is a suggestion that history is a mere flux, resulting from the chance workings of heredity. Finally, there is the striking and rhetorically deft opposition between "the personal, private and therefore universal and everlasting" on the one hand and "the merely historical and therefore transient and local" on the other. The "therefores" are what we need to attend to here, for with their help a paradoxical feat is performed:

19. Aldous Huxley, "Variations on The Prisons," in Themes and Variations (London: Chatto \& Windus, 1950), pp. 199-200. 
the most individual and personal elements in life become the most universal, while history becomes transient, local, and unimportant.

The explanation for this paradox is not far to seek, and Huxley is not alone in assuming its validity. Writing in another context, Hayden White usefully places Huxley in a long tradition of writers, starting fitfully in the nineteenth century and coming into its own only in the twentieth, who attack historicism and the historical consciousness in the name of "the essential contemporaneity of all significant human experience." ${ }^{20}$ At issue here is the freedom and power of the individual. In asserting that history is transient and local, Huxley is defending the power of the individual to transcend his or her own time and thus escape being historically determined. Freedom has dwindled to the chance play of hereditary factors, but that seems preferable to the vision of human beings as mechanically determined products which writers like Huxley believe nineteenth-century historicism to entail. The elevation of the human soul into the realm of freedom and universality depends upon breaking the iron chain of necessity by reducing history to flux. Devaluing history becomes a moral act that asserts human dignity, freedom, and moral responsibility.

When an extreme form of the view of history as flux underlies the reading of a novel, it can prevent a critic from recognizing the representation of history at all. This tendency is apparent in Dorothy Van Ghent's essay on The Heart of Midlothian. In her analysis, Van Ghent decries Scott as a money-grubbing hack; she tries to rewrite his novel, wishing it were Pride and Prejudice or Measure for Measure. For her, there is simply no place at all in a serious novel for the predominant representation of the past as past. She considers Balzac a true artist because when he creates a historical milieu, it functions as a "spiritual symbol." ${ }^{21}$ She has great contempt for Scott's protagonist, Jeanie

20. Hayden V. White, "The Burden of History," in his Tropics of Discourse: Essays in Cultural Criticism (Baltimore: Johns Hopkins University Press, I 978), p. 3 I.

2I. Dorothy Van Ghent, "On The Heart of Mid-Lothian," in The English Novel: Form and Function (1953; rpt. New York: Harper, 1961), p. I23; subsequent references appear in my text. Van Ghent derives her notion of the "spiritual symbol" from Coleridge (some of whose comments on Scott she misinterprets at the end of her essay). I discuss the problem of Coleridgean symbolism in historical fiction extensively in Chapter 3. For a more recent study that belittles Scott by measuring his works against an inappropriate standard, see David Craig, Scottish Literature and the Scottish People, I680-I830 (London: Chatto \& Windus, I96I), pp. I39-56, I66-88. Craig's conception of the novel derives from that of the Leavises. 
Deans. In particular, she cannot see the point of Scott's careful depiction of Jeanie's rigidly moralistic upbringing as a member of a dying Calvinist sect, the Cameronians:

The pressure placed on our actions by "conditions" is of the greatest dramatic and moral interest: it provided the most powerful source of ambiguity in ancient Greek tragedy, and it does so again today in the novels of Faulkner. But the "conditioning" of Jeanie Deans is not used as a source of ambiguity; it is, indeed, not used by Scott at all in the structure of the book. It is an element existing in the book; we are allowed to know and understand Jeanie's training in verbal scrupulosity; but we are not led thereby to penetrate into the complexity of our destiny as "conditioned" and yet morally independent creatures, as we are led to do by Sophocles and by Faulkner. Jeanie's Cameronian training is a mere bit of local color. [p. II9]

According to Van Ghent, the depiction of social and historical circumstances in prose fiction is justified only if it leads us to explore such matters as the timeless ambiguity of the human condition. Scott's fascination with the fact that people like Jeanie Deans actually existed in the past is trivial; it neglects what Hayden White calls "the essential contemporaneity of all significant human experience." True artists build their novels around the individual. Van Ghent elsewhere remarks that Scott's central weakness is that he does not realize that the fictional character ought to be "an inwardly complex agent out of whose human complexity evolve the event and the destiny" (p. I 24). The full implications of this statement for historical fiction are worth pondering.

It is only fair to add that as far as Van Ghent is concerned, her analysis of Scott does not imply a preference for probing the moral life of the individual instead of representing social and historical forces. Given the presuppositions she shares with Huxley, the historical setting of The Heart of Midlothian naturally appears to her to be what she derisively calls "local color," random antiquarian detail used to enliven Scott's plot. In a real sense she simply cannot see one side, the main side, of Scott's novel. Critical theories are lenses that are useful (and dangerous) because they exclude some things from view as a condition of focusing on others. Van Ghent's lens has, as we would have expected, reduced history to flux. 
Van Ghent has little of value to tell us about Scott or the historical novel in a positive way. She is useful, however, in reminding us of what we cannot expect to find in a novel like The Heart of Midlothian. She is certainly right, for instance, to note a lack of psychological depth in the portrayal of Jeanie Deans. On the other hand, her critical tenets produce better results with many of the greatest English novels. This implies two things. First, we require a set of critical presuppositions different from hers if the historical novel is to come into focus for us; in particular, we need a more flexible conception of the place of character and the direct depiction of consciousness in fiction. But second, her success with some distinguished standard novels suggests that weaknesses in the historical novel itself may account in part for her inability to deal with it adequately.

Why does Van Ghent's lens have the curvature it does? To be fair, it requires the affront Scott poses to bring out so baldly her presuppositions about form in the novel. In her essays on other novelists, she makes some attempt to deal with a variety of cultural issues; as a "second-generation New Critic," she is interested in treating novels as something more than self-contained urns. ${ }^{22}$ But for all that, we feel certain imperatives throughout her essays. In the last analysis, and often in the first analysis, she insists that contextual matters be mediated through individual interiority, depicted either directly or in symbolic form. Why this insistence on the primacy of individual consciousness as the grounds for literary structuring and thematics? Why must "the event" evolve from a character seen as "an inwardly complex agent"? What implicit criteria are at work here?

Van Ghent's notion of what novels ought to be and do is anything but idiosyncratic: it is based on a set of cultural presuppositions that inform the standard novel itself and render it intelligible. We can say that this set of presuppositions reflects bourgeois ideology and bourgeois individualism, so long as we use the terms with care. Both "bourgeois" and "ideology" are notoriously ambiguous and tendentious words, but I think we can make their difficulties work to our advantage. Here and throughout this book, I shall use "ideology" in a basically neutral sense, to refer to a culturally induced and shared set of beliefs through which we make sense of our world and act within

22. Daniel R. Schwarz, “The Idea Embodied in the Cosmology': The Significance of Dorothy Van Ghent," Diacritics, 8 (1978), 72-83. 
and upon it. ${ }^{23}$ But I do not want to drop out the pejorative connotations of the word altogether. The notion of "ideology" as "false consciousness" can serve to remind us that world views are never neutral and value-free, and that thought often involves mystification. My use of the term "bourgeois" is similar. Primarily, I intend it to refer to a class and set of class values that are centrally implicated in the rise of realist fiction and its flourishing in the nineteenth century. At its most pejorative, the notion of "bourgeois individuality" becomes synonymous with "privatization," reminding us that Van Ghent's radical valorization of human interiority, which reflects a valorization implicit in standard fiction itself, can haye the ideological effect of making readers ignore the social and historical realities around them. But at its best, bourgeois individualism and the ideology that surrounds it constitute a positive moment in the development of human consciousness. They have virtues we should be wary of relinquishing or denigrating, unless we are certain that they will be truly sublated, canceled but also preserved, in a higher form of consciousness and social practice. And they are valuable not least because they have enabled a particularly rich and fertile tradition of literary creativity. Van Ghent succeeds with many fine standard novels and fails with Scott, then, because she is working in a relatively uncritical fashion within the ideology that enables standard fiction. Her privileging of the "spiritual symbol" is another indication of her place in this tradition, which values the symbolic above the allegorical and the metaphorical above the metonymical.

Our discussion of the grounds of Van Ghent's strengths and weaknesses as a critic implies that the problem with historical novels is a special, extreme example of a problem with (some would say the glory of) standard fiction in general. To be sure, the novel is the form that most adequately depicts human beings in their full historical and social contexts: Lukács is right to consider it in this sense the most historical of genres. But though this is a real achievement, it is also a partial one. The novel has pitted interiority against social and histori-

23. Clifford Geertz, "Ideology as a Cultural System," in his The Interpretation of Cultures (New York: Basic Books, 1973), pp. 193-233, attempts to use "ideology" in a neutral way. For a survey of the various meanings of "ideology" in Marxist thought, see Raymond Williams, Marxism and Literature (London: Oxford University Press, I 977), pp. 55-7I. 
cal inclusiveness ever since Clarissa Harlowe revealed her soul in letters that gave a new concreteness to the depiction of a certain class at a certain time in history. ${ }^{24} \mathrm{~A}$ tendency toward absorption into the self is always there, though it reaches a greater intensity in many twentieth-century critics than it does in the nineteenth-century novels they describe.

The notion that bourgeois individualism informs the standard novel and guides its reception, I might add, explains why the distinction between "novels of the recent past" like Vanity Fair and "historical novels" like Henry Esmond or Waverley seems intuitively clear, though difficult to theorize. To the extent that we value bourgeois individualism and respond to its successful portrayal as the norm in the novel, we will tend to interpret standard novels as centering on the "timeless" individual unless we are positively prevented from doing so by some anomaly in their form. In most novels of the recent past, historical probability is present, but not in a strong enough way to shift our perception of their form; in historical novels, it is strong enough. ${ }^{25}$ We can also understand our divided reaction to Scott's own characterization in these terms. We need not explain away what we register as central weaknesses in that characterization as resulting simply from inappropriate expectations. This is part of the truth, but not the whole truth. Because of the way in which many of Scott's basic fictional techniques were developed by other authors, his novels seem to announce themselves and to some extent $d o$ announce themselves as part of the nineteenth-century bourgeois tradition in fiction and may be judged accordingly.

Van Ghent's rejection of Scott and the artistic possibilities of the historical novel is total. The Heart of Midlothian is not inferior in

24. I say Clarissa Harlowe, not Moll Flanders, on formal and ideological grounds. Rader, "Defoe, Richardson, Joyce," demonstrates that Richardson's novels are plotted actions and Defoe's are not. And Ian Watt, The Rise of the Novel: Studies in Defoe, Richardson, and Fielding (University of California Press, 1957), pp. I33-34, seems to me right in suggesting that Defoe's works challenged in advance certain values central to the standard novel that followed him.

25. For the useful term "novels of the recent past," see Kathleen Tillotson, Novels of the Eighteen-Forties (1954; rpt. London: Oxford University Press, I96I), pp. 92-93. I believe that the three uses of history in standard historical fiction which I outline in Chapter 2 could be profitably used to analyze novels of the recent past as well, since the two groups partially overlap in their formal problematic and their interest in history. 
some ways to Pride and Prejudice, it is "essentially valueless" (p. I I 4). But the criticism of W. J. Harvey, who works from a set of assumptions comparable in many respects to Van Ghent's, suggests that a less drastic judgment is possible. Harvey does not deal with the historical novel directly, but he does consider the question of what levels of human existence can be successfully represented in prose fiction. ${ }^{26}$ The partial success of Germinal, he believes, indicates that "many novels may approach if not achieve greatness by realizing through a host of background characters a sense of society in action" (p. 57). Harvey recognizes that Zola must keep his characterization schematic, since "more complex characterization or greater psychological subtlety would have compelled a different kind of interest, quite fatal to the book's distinctive achievement" (p. 58). But because this achievement demands that the novel lack a fully realized and individualized protagonist, Zola's novel cannot be truly great. Harvey would probably view historical novels in the same way.

Harvey draws his conceptual framework explicitly from Kant. It is not surprising that he should on the one hand speak of "the world of flux and historical relativity" (p. I9), while on the other hand stressing the dignity and importance of the individual. Harvey tells us that "most human beings will always elude or overflow the categories of any ideology" (p. 26), and he quotes with approval Robert Langbaum's notion that great fictional characters convey "the element we call individual because it eludes and defies classification ... that unlit area behind the Aristotelian agent in sensing which we sense what we mean by the character's life" (p. I 88). He dismisses the idea that beneath the flux of history lies an eternal human nature (and here he parts company with many critics who defend man's moral dignity against historical determinism). But he replaces the eternal human heart not simply with his own version of Kant's constitutive categories but also with a necessarily vague notion of eternal human mystery. The belief that human beings finally elude any of the categories that we use to describe them has for him important fictional implications:

To load the protagonist [of a novel] with a great deal of generalized, representative value is always a tricky business since what we attend

26. Harvey does give a brief negative judgment of George Eliot's Romola (p. 30). 
to in his story is the individual, the unique and particular case. It is his story and his alone. ... We quickly feel uneasy if the protagonist is made to stand for something general and diffused; the more he stands for the less he is and we may soon end up with an allegorical figure, an Everyman. Of course, many protagonists are in a sense Everyman but only because they are in the first instance a particular man; if the protagonist is in some way a universal value or meaning, he is primarily a concrete universal. [pp. 67-68]

Generalized meaning ought in Harvey's view to be expressed through minor characters, who can function as the reader's "delegates" in a novel, provide "the comfortable recognition of the typical," and "bear the weight of a good deal of symbolic value" (p. 67). Zola's major characters are thus too generalized to be true protagonists: they are merely inflated minor characters. Much of Harvey's discussion is admirably attuned to the way in which standard novels operate. His brief introduction of the Hegelian concrete universal into his Kantian framework, however, raises more difficulties than it solves. If standard novels in fact can have protagonists who are concrete universals, then the representational problems Harvey so clearly identifies in Zola's novels ought not to exist, at least not as part of an inescapable trade-off between social and individual representation. Harvey's analysis reveals but then ignores the limits of mimesis in standard fiction.

Van Ghent and Harvey express two versions of the attitude toward social and historical mimesis in fiction which I take to be central to English-speaking novel criticism in this century. Van Ghent seems to believe that the distinctively historical part of human life is not a proper subject for art at all, because it is external and inessential. Harvey believes that history and society are important, but that too great an interest in representing them will necessarily flaw a novel. For both critics, human value and the proper sphere of art reside in the individual consciousness: it is either undesirable or impossible to represent the entire spectrum of human existence in any work. In practice, we must choose between the particular and the general. We should choose the particular, for if we dig deeply enough into the individual soul, we shall discover there the universal and eternal part of humanity.

If criticism based on bourgeois ideology has had only a limited suc- 
cess with Scott and the historical novel, it would seem natural to turn to criticism of a different ideological persuasion. The obvious choice is Lukács. For Lukács, the problem of social mimesis takes on significantly different contours because he approaches it with different assumptions. The critics whom we have discussed believe that human beings are at their most human as individuals and that history is without meaning, except in terms of the individual. For Lukács, human beings reach their fullest humanity not as isolated individuals but in society, and history is a process that can be objectively understood. Lukács does not believe that art should concern itself exclusively with that part of the spectrum of human existence which the "individualist” critic finds unimportant. In fact, Lukács describes Zola's novels in much the same way as Harvey does. According to Lukács, Germinal is faulty because it creates abstract pictures of general types at the expense of human particularity. Where Lukács differs from Harvey is in the extent of the human spectrum he thinks art can represent. For Harvey, Zola's defects are the necessary consequences of his virtues. For Lukács, they are mistakes, which reflect a bad esthetic theory. ${ }^{27}$ The finest works of literature embody a quality that Lukács calls "realism." They are able to represent all levels of human existence at once, because history has an unfolding meaning to which all the particularities of daily life are ultimately related. This meaning is available to cognition, and also to esthetic intuition. Lukács's belief that history is a coherent process that can be represented in art provides the ultimate grounds for his judgment that realist art constitutes a mode of knowledge which provides "a different, but no less truthful picture of reality than does natural science." 28

Realist fiction captures all levels of our experience by creating what Lukács calls "typical" characters. This is a pivotal concept for his discussion and for our own:

27. Lukács, The Historical Novel, pp. I 71-250; see also "The Zola Centenary" (Moscow, 1940), in Studies in European Realism (1935-46), trans. Edith Bone (London, I950; rpt. New York: Grosset \& Dunlap, I964), pp. 85-96. In preferring the royalist Balzac to the radical Zola, Lukács follows the lead given by Engels in his famous letter to Margaret Harkness (April i 888).

28. Georg Lukács, Realism in Our Time: Literature and the Class Struggle (1957), trans. John and Necke Mander (London, 1962, as The Meaning of Contemporary Realism; rpt. New York: Harper, I97I), p. I 24. 
What is the key to these "typical" heroes of literature? The typical is not to be confused with the average (though there are cases where this holds true), nor with the eccentric (though the typical does as a rule go beyond the normal). A character is typical, in this technical sense, when his innermost being is determined by objective forces at work in society. Vautrin or Julien Sorel, superficially eccentric, are typical in their behaviour: the determining factors of a particular historical phase are found in them in concentrated form. Yet, though typical, they are never crudely "illustrative." There is a dialectic in these characters linking the individual-and all accompanying accidentalswith the typical....

The heroes of ... schematic literature ... altogether lack these features. They are not typical, but topical. Their features are prescribed by a specific political intention. I should add that it is always extremely difficult to isolate "typical" features. The typical hero reacts with his entire personality to the life of his age. . . . The characters produced by the schematists, on the other hand, are both above and beneath the level of typicality. The individual characterization is beneath it (whereas Natasha Rostova's "tripping step," say, or Anna Karenina's ball costume are unquestionably typical), whereas what is intended to establish their typicality may be irrelevant to their psychological make-up. This weakness is common, of course, to all naturalistic literature-Zola's "typical" characters have similar shortcomings. ${ }^{29}$

For Lukács, then, even the smallest detail describing a typical character is lit up with wide-ranging significance. In the view of Van Ghent or Harvey, the greatness of fictional characters resides in that region of the individual soul for which historical and ideological categories cannot account, "that unlit area behind the Aristotelian agent in sensing which we sense what we mean by the character's life." For Lukács, such talk is mere obscurantism. In his view, the more significant an index of historical process a character is, the more humanly true and esthetically powerful he or she becomes.

29. Realism in Our Time, pp. I22-123. In his later work on esthetics, Lukács creates a special category of reality in which typical characters exist, the category of "specialty" as opposed to the individual or the universal. For "specialty," see Lukács, Probleme, pp. 539-789; Lukács, Eigenart, II, I93-266; and Királyfalvi, pp. 7I-87. Fleishman (pp. I I-I3) calls on Wilhelm Dilthey to resolve the same problem which "typicality" and "specialty" solve for Lukács. According to Fleishman, Dilthey believes that history can be made sense of only in terms of the shapes of completed human lives. Using this notion as the key to interpreting historical fiction throws too much emphasis on the role of protagonists, who often function primarily as narrative devices, not as symbolic expressions of an author's view of history. 
I find Lukács's argument compelling. He has a profoundly moral view of literature, its function and importance; his esthetic system as a whole possesses a depth, coherence, and consistency that I can only suggest in a brief review of those aspects most relevant to my own interests. His analysis and use of the concept of "the present as history" are fundamentally important for any study of the relationship between history and literature. Furthermore, and this is not always recognized, his analyses of individual works are often brilliant and undogmatic. Nonetheless, I must dissent from his views at a fairly basic level and in a number of areas.

My most fundamental disagreement with Lukács involves his belief in the power of typical characters to represent all levels of man's social existence. ${ }^{30}$ The difficulty here is that the idea of the "typical," like Harvey's borrowed "concrete universal," precludes a strong explanation of certain weaknesses in Scott and historical fiction in general of which Lukács's own discussion betrays he is aware. The problem with typicality in Lukács is a complicated matter, which can be approached in a number of ways-in terms of foreground and background, of "enactment," or of what we as readers need to bring to a work as opposed to what it dramatizes for us. I admire Lukács's boldness and consistency in telling us that in War and Peace Natasha's "tripping step" is "undoubtedly typical," but I do not quite believe him. The problem that I am pointing to tends to be harder to see in his comments about novels, the works his theories fit best; it is much more visible when he discusses lyric poetry. Lukács says-as he must, given his belief that the true subject of all art is man as a social being - that even lyric poetry describing simple natural beauty "betrays the position that the poet takes with regard to the truly great currents and battles of his age." ${ }^{31}$ This assertion seems questionable. Two issues are involved here. The first is that there are surely some

30. For a discussion of the central place "typicality" holds in Lukács's intellectual system as a whole, see Rolf Günter Renner, Asthetische Theorie bei Georg Lukács (Bern: Francke, 1976), pp. 67-80. Peter Demetz, Marx, Engels and the Poets: Origins of Marxist Literary Criticism, trans. Jeffrey L. Sammons, rev. ed. (Chicago: University of Chicago Press, 1967), pp. 133-38, discusses the source of this concept; both Demetz and Renner point out its kinship with the Hegelian "concrete universal."

31. Királyfalvi, p. I 23; the passage appears in Eigenart, II, 640. In Probleme, p. 769 , Lukács also asserts the larger cultural resonances of lyric poetry and remarks that Natasha's "tripping step" is just as evocative as any lyric metaphor. 
areas of privacy in human existence to which the great currents and battles of an age do not penetrate, particularly in the brief lyric moment. That they do not so penetrate may have political and ideological implications and necessitate "symptomatic" analysis, but that is another matter. Beyond this lies another problem, raised by Lukács's formulation that lyric poetry betrays a poet's position about great social issues. In my view, we have a right to expect that a work of art will not only betray things but also enact them. As an object of cultural ỏr historical analysis, a novel may passively betray a great deal about a society; as the producer of an esthetic response, it must play a more active role. It may be that if we come to a work with a certain theory about society in mind, it will provide evidence for our hypothesis. But we may also be interested in what issues or feelings a work actively dramatizes. In some details of a novel, historical content may be in the foreground, whereas in others it may drop so far into the background that it disappears. The process of determining what is in the foreground of a work is often difficult and controversial, but we must and in practice do engage in it whenever we make sense of a work of art. And in fact, this is a process which Lukács himself constantly engages in when his criticism is at its best. His celebrated distinction between realism and naturalism is meaningless except in terms of formal priorities and active literary enactment, for he values realism over naturalism precisely because he sees realism as a mode which actively grapples with and reduces to knowable order the phenomena of historical life.

I realize that in my critique of Lukács, I am privileging the category of the esthetic, and thus inviting the charge that I myself am complicit in the very bourgeois ideology whose effects I have deplored in Van Ghent. ${ }^{32}$ I would reply that there are different degrees and modes of complicity, and that one can think of worse ideologies with which to be tentatively complicit if one wants to understand Scott and the standard historical novel. Beyond that, I am in fact simultaneously promoting and demoting the category of the esthetic. I am suggesting

32. Terry Eagleton, Marxism and Literary Criticism (London: Methuen, 1976), pp. 56-57, accuses Lukács himself of fetishizing the esthetic. He quite properly explains Lukács's value for the esthetic as a result of his residual ties with the German Humanist tradition, though he neglects to mention that precisely those ties account for some of Lukács's best criticism. 
that there may exist important areas of human experience which cannot be easily dramatized in literary form; indeed, works of which we highly approve on esthetic grounds may even blind us to social, historical, and moral problems and responsibilities. They may, but they needn't-unless we mystify the esthetic by ignoring its equivocality as a category and equating it with the cognitive or the moral or the historical. Symptomatic readings, which uncover what a work of art betrays by its volubilities and silences, are important, but they do not exhaust what we can know and need to know about literary works. Indeed, symptomatic readings are likely to be misleading when they do not use esthetic readings as their points of departure. ${ }^{33}$

Let me repeat that I do not mean to deny Lukács's assertion that the great achievement of nineteenth-century realism was to enable prose fiction to encompass a broader segment of the scale of human existence than it had included before or has since. But there are limits to this achievement. If what we require is active representation, I think we are bound to conclude that even in the greatest realist fiction, characters cannot represent all levels of human existence at once. Lukácsian typicality cannot solve the problem with historical novels. The idea of "typical" characters can be very helpful, though, if we use it in a more modest way than Lukács himself does, to describe characters who actively represent that part of the spectrum of human existence where the individual and society meet. We can then make a useful distinction between characters who are historically "typical" in that they represent salient aspects of a historical milieu, and characters who are simply historically "probable" members of that milieu. Characters who are nothing more than historically probable can of course be placed in relation to the salient forces in their milieu, if it is depicted as a systematic whole. But they promote historical meanings indirectly if at all: they require symptomatic reading to gain substantial historical significance, whereas symptomatic reading would either extend, revise, or contradict the historical significance that is already central to typical characters. ${ }^{34}$

33. For "symptomatic" reading, see Louis Althusser, "From Capital to Marx's Philosophy," in Reading Capital, by Louis Althusser and Etienne Balibar (I968), trans. Ben Brewster (London: New Left Books, I970), pp. I3-69.

34. For a concrete example of this distinction, see my comparison of Milnwood and the Baron of Bradwardine in the discussion of Old Mortality, Chapter 4. Another 
For all his love of Scott, Lukács is suspicious of historical fiction. Much of his classic study The Historical Novel demonstrates that novel after novel is decadent and unsatisfactory. I do not quarrel with his negative assessment of many of the works he discusses or with his respect for Scott. I do disagree with his justification for these judgments. His underlying rationale becomes clear if we recall the distinction between "the past as past" and "the present as history." For Lukács, the proper function of historical fiction is to provide a representation of historical process which promotes the discovery of the present as history. He is not interested in the depiction of the past as an object in its own right: in fact, he tends to deplore it. In neglecting the problems involved in depicting the past as past, Lukács not only fails to account for the distinctive formal strengths and weaknesses of historical fiction, he also cuts himself off from recognizing the full esthetic situation from which the very sense of history he so admires arises in the best historical fiction. ${ }^{35}$

Basic judgments about historical fiction necessarily rest upon assumptions about the nature of history itself. If we believe that history is flux, it is likely that we will assign its representation in prose fiction a low priority. Our conclusions will be different if we believe that history is a coherent process with an emerging meaning available to artistic intuition and capable of being represented by esthetic means. Since I have scrutinized the underlying assumptions of others in this regard, it seems only right to indicate my own. My views stem primarily from work with literary texts, but they are supported and clarified by the speculations of Siegfried Kracauer concerning the nature of history and historical understanding.

I find two of Kracauer's ideas particularly useful: his belief that his-

\footnotetext{
"probable" character is the Laird of Dumbiedikes, whom I contrast with the "representative" Duncan Knockdunder in the discussion of The Heart of Midlothian, Chapter 5 .

35. Lukács's theory of literature is by no means the "simple" reflection theory it is sometimes said to be, but it does not wholly escape a major problem inherent in all reflection theories-that the unmediated passivity of the metaphor of reflection itself tends to weaken the recognition that literary mimesis is an active, constructive process. For a discussion of the complexities of Lukács's reflection theory, see G. H. R. Parkinson, "Lukács on the Central Category of Aesthetics," in Georg Lukács: The Man, His Work, and His Ideas, ed. G. H. R. Parkinson (London: Weidenfeld and Nicolson, 1970), pp. 109-46. On the weaknesses inherent in the reflection metaphor, see Williams, p. 97.
} 
tory is nonhomogeneous in structure, and a corollary principle that he calls the law of perspective. Kracauer points out that historians who work at different levels of human generality usually assume that in principle their work is theoretically compatible-that all the findings of microhistory will eventually lead up in a smooth and seamless way to the broadest, most inclusive generalities of macrohistory. Thus the macrohistorian Arnold Toynbee believes that his historical generalizations will ultimately mesh with the most detailed work on individual historical topics. Kracauer thinks that this faith is an illusion: "Toynbee's suggestion of a merger of the bird's-eye view [of macrohistory] and the fly's-eye view [of microhistory] is in principle unfulfillable. The two kinds of enquiry may co-exist, but they do not completely fuse: as a rule, the bird swallows the fly." ${ }^{36} \mathrm{He}$ describes this phenomenon in terms of a law of perspective. As we ascend progressively higher over the historical terrain, events and situations begin to blur and their full particularity is lost; different patterns emerge at different altitudes. This should not surprise us: that "macro realities are not fully traceable to the micro realities going into them-that interrelated events at low and higher levels exist, so to speak, side by side-is by no means an uncommon phenomenon. Most individuals behave differently in different dimensions of being" (p. II 7 ). This "side-by-side" philosophy makes him interested in phenomena occurring on all levels of generality. He is not tempted to dismiss the historically particular as involving mere "local color," but instead defends the historical "collector" for redeeming aspects of the past from oblivion. Such a viewpoint is useful in dealing with an author like Scott, whose fiction is fundamentally informed by a desire to preserve the remnants of Scotland's past.

The ultimate justification for Kracauer's views is philosophical. It involves the relationship between particulars and universals, which he believes traditional philosophy has misconceived. Philosophers have assumed that "the highest principles, the highest abstractions, not only define all the particulars they formally encompass but also contain the essences of all that exists in the lower depths" (p. I30). But this is false: "philosophical truths do not fully cover the particulars logically subsumable under them" (p. 212). In a formulation I find

36. Siegfried Kracauer, History: The Last Things before the Last (New York: Oxford University Press, I969), pp. I 27-28; subsequent references appear in my text. 
particularly useful, Kracauer asserts that "it is doubtful indeed whether the truths of the highest generality are capable at all of rousing the particulars they logically encompass. These extreme abstractions crystallize into statements so wide-meshed that the particularsa series of historical events, or so-cannot but drop through the net" (p. IO2).

Whatever we think of the ultimate validity of Kracauer's philosophy of history, it illuminates a critical problem inherent in writing historical fiction. ${ }^{37}$ I am not entirely convinced that his "law of perspective" holds for all philosophies of history, though it surely underlines in a pointed and useful way a problem they must address. It may also not apply to all historical narratives, especially when their writers adopt the technique of running up and down the scale of human generality, as Edmund Wilson tells us Michelet does: "Michelet's skill at shifting back and forth between the close-up of the individual, the movement of the local group and the analytical survey of the whole, is one of the features of a technical virtuosity which becomes more and more amazing." 38 But I am convinced that standard historical fiction cannot enact all levels of human experience with equal success. Unlike Michelet, the standard historical novelist cannot create a texture that is primarily analytical and descriptive, and then particularize it through imaginative excursions into groups and individuals. Tolstoy may be reaching toward such a form when he writes the analytical chapters in War and Peace. But what a small proportion these comprise of his novel as a whole, and what scandal even they have caused among lovers of the standard novel!

Kracauer tells us that in historiography, the fly's-eye view and the bird's-eye view cannot coexist-usually, the bird swallows the fly. In standard historical fiction, the fly is just as likely to swallow the bird. When it does not, when fictional plots and characters are adapted to dramatize historical process, a price must be paid. As characters become translucent to allow historical processes to shine through them

37. Martin Jay, "The Extraterritorial Life of Siegfried Kracauer," Salmagundi, 31-32 (Fall I 975-Winter 1976), 49-109, points out that Kracauer's philosophy of history runs the risk of hypostatizing modern anomie and his own consciously chosen position as an outsider into a universal law of cognition.

38. Edmund Wilson, To the Finland Station (1940; rpt. New York: Doubleday, 1953), p. 18. 
more clearly, they also tend to become thinner as representations of "inwardly complex" human beings.

Is there a problem with standard historical fiction? I conclude that there is. ${ }^{39}$ When W. J. Harvey and Dorothy Van Ghent stress the primacy of the individual, they may or may not be enunciating an eternal truth, but they are indicating the area of life with which standard fiction is best equipped to deal. In standard novels, protagonists are characteristically at the center of things. Milieu, minor characters, and plotted action are there to illuminate them. This formal arrangement has many virtues, but it conflicts with the priorities of historical fiction. Historical fiction often employs characters to represent salient aspects of a historical milieu. In the greatest historical fiction, characters and narrative sequences elucidate historical process. But if historical novels attempt to use plot or milieu primarily for the sake of illuminating individual consciousness or moral choice, they risk blurring their distinctively historical focus. In historical fiction, character is likely to illuminate historical events and destinies, not to act as "an inwardly complex agent out of whose human complexity evolve the event and the destiny." It would be foolish to deny that this is a limitation, but historical fiction has its compensations. It is tempting to suppose that all important aspects of life can be fully explored by the literary forms we most admire. I believe that this is untrue, and that it is also wrong to assume that an area of life is trivial because it cannot be so represented. Because history matters, it is worth understanding the limitations of historical novels and then using this understanding to discover and enjoy their strengths.

39. John Maynard, "Broad Canvas, Narrow Perspective: The Problem of the English Historical Novel in the Nineteenth Century," in The Worlds of Victorian Fiction, ed. Jerome H. Buckley, Harvard English Studies, 6 (Cambridge: Harvard University Press, I 975), p. 242, recognizes the problem but does little with it, perhaps because of his impatience with generic distinctions. For him, the problem with the English historical novel turns out to be cultural cowardice about facing up to history, and works like The Red and the Black, which treat the present as history, solve whatever problems historical fiction poses. Peter K. Garrett, The Victorian Multiplot Novel (New Haven: Yale University Press, I980), p. I6, believes that "the common and distinctive structural problematic of the major Victorian multiplot novels" involves the dialogue within them between social and individual perspectives. His use of Mikhail Bakhtin's notion of "dialogical form" enables some interesting readings, but it also tends to explain away structural problems and disregard the importance of the ideological contradictions with which they are associated. 
My discussion has attempted to open the way for a new look at standard historical fiction and at Scott's novels, by suggesting the diverse and inherently problematical nature of these works. In the following chapters I hope to give a reasonably systematic view of the different ways in which they employ history and cope, or fail to cope, with the problems that result. 